\title{
CONCURRENT OVER- AND \\ UNDER-TREATMENT IN \\ DICTIONARIES. A RESPONSE
}

\section{Willem Botha: Editor-in-Chief of the Woordeboek van die Afrikaanse Taal (wfb@sun.ac.za)}

In my response I will attempt to establish what the WAT, Afrikaans lexicography and lexicography in general can gain by a discussion of GillesMaurice de Schryver's article. Let me start by expressing my appreciation for G.-M. De Schryver and D.J. Prinsloo's efforts to develop a 'Ruler' for all eleven official languages of South Africa. I have no doubt that their efforts can make a big contribution to South African lexicography. I, however, also want to respond to the main arguments or points of criticism regarding the WAT.

\section{Background}

The Woordeboek van die Afrikaanse Taal was redesigned in 1989 (cf. Botha 1994 and 2003). Production was stopped for almost a year and with the reviews of the first eight volumes, the assistance of metalexicographers and the insights of the lexicographical theory of the time as foundation, a new style guide was developed. That the WAT took cognisance of criticism is evident from the fact that none of the main points of criticism against the first eight volumes is repeated in the criticism of volumes IX and X. Encyclopaedic treatment of lexical items, complexity or incomprehensibility of meaning descriptions, ill-judged use of citations (ranging from almost no citations in the first volume to a superfluity in volumes six to eight), an abundance of highly technical terms entered as lemma signs, slow alphabetic progress, scant morphological information and the absence of consistent pronunciation guidance therefore do not feature in the predominantly positive criticism on volumes IX and X. The main points of criticism against the ninth and the tenth volumes have already been reacted to in volumes XI and XII, of which the latter is in preparation. Volumes IX to XI ( $\mathbf{L}, \mathbf{M}, \mathbf{N}$ and $\mathbf{O})$ therefore represent a new dictionary after an about-turn at the halfway mark. The ideal of the WAT, however, remains that the interaction between lexicographic theory and practice should be a dynamic process. 
Prinsloo and De Schryver (2003) reported in a Festschrift for Dirk van Schalkwyk on the development of a Ruler for Afrikaans. In this article (written in 2002) they concentrated on the effective alphabetic progress made from volume IX (L) of the WAT onward. In terms of space allocation it was stated that the correlation with the Ruler was 'remarkable'. Statistics, however, also showed a large difference between lemma signs that should have been included in volume XI according to the Ruler, and the actual number of lemma signs in volume XI. In the article now under discussion De Schryver proceeds to analyse this deviation from the Ruler developed for Afrikaans. In his analysis he could also utilise the electronic version of the WAT (A to $\mathbf{O}$ ), which became available in March 2003.

\section{On a Ruler for Afrikaans}

The Ruler for Afrikaans is based on a relatively large electronic corpus and five popular Afrikaans desk dictionaries. It is not clear how the corpus has been composed. Afrikaans desk dictionaries are notorious for not being compiled from a corpus, but according to the intuition of the compilers. In our experience Afrikaans desk dictionaries include many items that would not stand up to corpus scrutiny, like Dutchisms, and they copy each other in terms of lemmatisation and also use Dutch desk dictionaries as models (cf. Odendal 2003 and Prinsloo 1991). I do not believe that the inclusion of the desk dictionaries in the ruler is warranted, owing to their inherent deficiencies.

I therefore have some doubt whether the data resources on which the Ruler is based, can be considered as balanced and can give frequency counts that accurately reflect Afrikaans. If a different selection of Afrikaans desk dictionaries and corpora are used, as De Schryver reports, the same concerns still apply.

Irrespective of whether it is balanced or not, the composition of the data resources is to a large extent not comparable with that of the data resources of the WAT. These include spoken as well as written language, formal as well as informal language, regional as well as standard language, the different variations of Afrikaans, examples of archaic lemmas, obsolete lemmas or lemmas becoming obsolete and lemmas representing a variety of registers. When work on the letters $\mathbf{N}$ and $\mathbf{O}$ commenced, the editors had the following data resources at their disposal:

(1) Paper slip citation collection. This citation collection roughly spans a period from about 130 years ago up to the present. It consists of about 3,5 million cards containing citations from literature, newspapers, magazines and many other publications. Spoken language is also recorded on the cards.

(2) Electronic citation collection. This is a collection of citations from literature, newspapers, magazines and other publications, especially from 1990 onwards. It contains page references as part of comprehensive source 
references and consists of around 4 million words (tokens) and 210,000 unique words (types). It serves as a hybrid corpus, because full text searches are done.

(3) Nasionale Pers Archives.The Nasionale Pers Archives is a large electronic selection of Afrikaans newspapers and magazines. It allows frequency counts.

Since 2001 when work started on the letters $\mathbf{P}$ and $\mathbf{Q}$ editors also have access to the Afrikaans Newspaper Corpus which allows frequency counts and advanced searches, and the Electronic WAT which allows full text searches from A to $\mathbf{O}$ in the dictionary. A Ruler for Afrikaans, or any other language, can be to the advantage of lexicographers and can be a valuable guideline. The WAT's resources could play a role in refining the Ruler for Afrikaans and I would therefore like to invite the author to consider involving the data resources of the WAT in refining the Ruler for Afrikaans. There is great potential for partnership and co-operation, both practically and academically.

\section{On average article length in the Woordeboek van die Afrikaanse Taal}

An about-turn at the halfway mark of a comprehensive dictionary can either be regarded as gallantry or folly. It is bound to cause inconsistencies in a dictionary published volume by volume, or letter by letter in the electronic era. Even before the big changes at the halfway mark, the ideal of uniformity was discarded and several changes aimed at improving the quality of information in the WAT were implemented. It is indeed, as Gouws (1999: 4) pointed out, the result of 'an initial lack of lexicographic planning'.

After the publication of volume I (A to C) more and more data types were being added from letter to letter, mostly caused by the WAT's response to criticism. The fact that 'on average, 5 times more space is devoted to each lemma sign under $\mathbf{O}$, as compared to the space devoted under $\mathbf{B}$ ' is a direct result of this tendency.

From $\mathbf{A}$ to $\mathbf{C}$ the minimum microstructural treatment was provided. In many cases only a definition was supplied with no pronunciation guidance, part of speech indication, morphological information or illustrative material (citations, collocations and the lexicographers' own examples). Illustrative material normally takes up most of the space in the articles of a comprehensive dictionary. The articles under $\mathbf{A}, \mathbf{B}$ and $\mathbf{C}$ therefore take up very little space and this causes a big contrast between the number of lemma signs per page under $\mathbf{B}$ and $\mathbf{O}$ respectively. Under $\mathbf{O}$ every lemma sign received full microstructural treatment.

The WAT had to choose between a uniform (and incomplete) presentation of information from the beginning to the end of the alphabet (which inter alia prevents the increase of the length of articles), and a dynamic interaction 
between lexicographic theory and practice. The latter was chosen, which led to the inconsistencies pointed out by De Schryver.

\section{On concurrent over- and under-treatment in the Woordeboek van die Afrikaanse Taal}

The statement is made that in comparison to the Ruler for Afrikaans a very large number of lemma signs are not entered under $\mathbf{L}, \mathbf{M}, \mathbf{N}$ and $\mathbf{O}$. It is difficult to respond to this statement as no specific lemma signs are mentioned. It is clear, however, from section 5 that the key issue here concerns the question: what qualifies as a macrostructural item? It seems that although unexplained sublemma signs with limited or even no microstructural treatment are recognised in lexicographic theory as part of the macrostructure of a dictionary, De Schryver does not count them as part of the macrostructure of the WAT (cf. Wiegand 1989, 2002, 2002a and Wolski 1989). The same applies to lemmas listed under sublexical lemma signs or hyphenated lemma signs like on- ('un-') and expressions entered with full microstructural treatment in separate sections for expressions in the articles of one of the main components of the expressions.

\section{On volume $\mathrm{XI}(\mathrm{N}$ and $\mathrm{O}$ ) of the Woordeboek van die Afrikaanse Taal}

De Schryver found that the WAT articles per page remained rather constant at 15 for 3150 pages. The alphabetic stretch KLA to $\mathbf{N}$ averages 15 articles per page, although KLA to the end of $\mathbf{K}$ represents the 'encyclopaedic' phase of the WAT. It can be argued that this is caused by the fact that $\mathbf{K}$ contains extreme examples of 'concurrent under- and over-treatment'. Kokosneutsap to koksidiö̈dien (page 692 of volume VI) contains 44 articles of which 5 consist of only two words, e.g.:

\section{kokosneutvet Klappervet}

Seven more articles only consist of 3 words only and so the pattern continues. Most of these very short articles should probably never have been included as the usage frequency of the lemma sign is very low. Throughout the letter $\mathbf{K}$ such short articles are alternated with encyclopaedic articles such as those of kleur ( 8 pages of which 4 are colour illustrations), knoop (5 pages), knop (4 pages), koers (4 pages) and koffie (4 pages). From the letter $\mathbf{L}$ onward such extremes in article length were terminated with each main lemma sign receiving full microstructural treatment, while avoiding an encyclopaedic character. This resulted in the continuation of an average of 15 articles per page. De Schryver, however, points out that the largest part of the letter $\mathbf{O}$ in the last volume of the WAT has an average of 12 articles per page. This leads to his question 'whether 
or not important items are now perhaps also absent from the last WAT volume'.

He then argues that a comparison between a desk dictionary like the HAT and the WAT could provide an answer to this question. His argument is that 'given the respective sizes of HAT versus WAT, it seems sound to assume that all (correct) lemma signs found in the $\mathbf{N}$ and $\mathbf{O}$ macrostructure of HAT have also been fully treated in Volume XI of WAT'. This is, however, not necessarily the case as many Afrikaans desk dictionaries such as the HAT are not compiled from a corpus, or even not according to any extensive database, but according to the intuition of the compilers. As I have pointed out previously, this leads to various deficiencies. He finds that 695 'correct' lemma signs in HAT under $\mathbf{N}$ and $\mathbf{O}$ do not appear 'as articles in their own right in WAT'. De Schryver groups the lemma signs into five categories and then gives examples of lemma signs.

Category one: specialised expressions, namely Olimpiese Spele 'Olympic Games'. This item is, however, treated in a sub article of 32 lines in the article of Olimpies, but is seemingly not recognised as a lemma sign (see figure 1).

Category two: 'Untreated sub-lemmas', namely oorheersing, oorgehaal, opgelê, opgewen, onverklaarbaar, narigheid, nierkwaal. The WAT refers to these examples as 'unexplained macrostructural items with limited microstructural treatment'.

oorheersing 'domination': this item is entered as an unexplained derivative in the article of oorheers. It was considered to be a semantically transparent and morphologically regular derivative. The same applies to the derivatives onverklaarbaar and narigheid and the compound nierkwaal. The question of transparency will always be open to debate and subjective. The lexicographer has to make assumptions as to which compound nouns or derivatives the target users of the dictionary may experience as transparent. Béjoint (1999: 84) correctly surmises that 'the actual transparency of a compound noun varies according to the ability of each language user to understand its elements'. It can be argued that the WAT's target user group consists of relatively sophisticated language users and that the editors could therefore assume transparency in more cases. The microstructural treatment in the WAT includes an indication of part of speech and stress:

\section{oorheer'sing s.nw.}

In the cases of opgelê, opgewen and oorgehaal it was judged that they are merely regular past participle forms of oplê, opwen and oorhaal with no added semantic value.

Prinsloo and De Schryver (2002: 492) mention that the 'unnecessary treatment of transparent compounds' was one of the 'major points of criticism 
'Olimpies [oləm'pis / ulam'pis] b.nw., Olimpiese.

1 Van, afkomstig van, wat betref, behoort tot of eie is aan die Olimpiese Spele ('OLIM. PIES, uitdr.): Olimpiese byeenkoms, doelstelling, dorp, handves, ideaal, kampioen, medalje, rekord, span, stad, titel, vlag. Olimpiese deelnemers, sportsoorte, standaarde, wenners. Die Olimpiese simbool, vyf aaneengeskakelde ringe, dui op die vyf vastelande ... Dit stel die welwillendheid tussen al die nasies van die wêreld voor (Beeld, $3 \mathrm{Mrt}$. $1968,21)$. Die maatskappy het ... R18 miljoen vir 'n Olimpiese stadion beskikbaar op voorwaarde dat hulle ook die bouwerk doen (Tegniek, 20 Des. 1985, 18)...

UITDR.

GESPESIALISEERD

Spele: Olimpiese Spéle

1 Sportbyeenkoms, i.d. tradisie en gees v.d. Olimpiese Spele, by bet. 2 hieronder beskryf, wat sedert 1896 op 'n moderner grondslag gehou word en waaraan nasies v.d. vyf kontinente vierjaarliks in 'n verskeidenheid sportsoorte teen mekaar meeding; sin. Moderne Olimpiese Spele, Moderne Spele; Olimpiade (ongewoon): Die amptelike opening van die skouspelagtige Olimpiese Spele wat in 1936 in Berlyn gehou is. Ná 36 jaar is daar ... weer 'n Olimpiese Spele in Duitsland (Huisg., 18 Aug. 1972, 40 - byskr.). Thugwane het met die goue medalje wat hy ... in die Olimpiese marathon (in 1996) gewen het ook die Suid-Afrikaanse span gehelp om die vyf medaljes te ewenaar wat in 1932 by die Olimpiese Spele in Los Angeles gewen is (Beeld, 5 Aug. 1996, 1).

2 Sportwedstryde ter ere v.d. god Zeus wat vanaf 776 v.C. tot 394 n.C. elke vier jaar op die vlakte van Olimpië gehou is, waaraan slegs mans kon deelneem en wat aanvanklik slegs naellope en stoei ingesluit het, maar later o.a. ook strydwarenne en musiek- en welsprekendheidskompetisies; sin. Antieke Olimpiese Spele, Antieke Spele; Olimpiade (ongewoon): Ongeveer die tyd toe Koroibos die wenner was van die eerste Olimpiese Spele wat in Griekeland gehou is ..., is die profeet Jesaja in Jerusalem gebore (F.C. Fensham, vert.: Woord, 1961, 60).

Figure 1:

generally expressed against WAT' before the dictionary was redesigned in 1989. The method of entering transparent compounds and derivatives as sublemma signs with limited microstructural treatment is partly the result of the WAT's reaction to this criticism. The fact that some semantically transparent compounds and derivatives have a high frequency does not change the fact that they do not need to be explained. It only makes their inclusion in the macrostructure of the dictionary desirable. 
According to Wiegand (2002, 2002a) the WAT's unexplained compounds and derivatives qualify as main lemmas. For Wiegand a macrostructural element is considered a sublemma when it can only be accessed via an entrance lemma because textual condensation has resulted in the horizontally-ordered macrostructural element being a partial lemma with a placekeeping symbol substituting the first stem. This is the method applied by HAT. In the HAT article of nier the following examples of unexplained sublemma signs are entered: nier: -aar, -bekken, -lyer, -vormig. In the judgement of the WAT not one of these examples are transparent and nieraar, nierbekken, nierlyer and niervormig are lemmatised with full microstructural treatment 'as articles in their own right' in volume XI. Relevant questions therefore are: When is a lexical item considered to be transparent? This is a subjective matter and the WAT and the HAT clearly differ in their approach to this question (cf. Béjoint 1999). Are unexplained sublemma signs part of the macrostructure? In our view the answer to this question is positive and this is also a prominent view expressed in some current metalexicographic literature (cf. Wiegand 1989, 2002, 2002a and Wolski 1989).

Category three: 'untreated run-ons', namely ondervoorsitter, ongehoorsaam, ongesond, onaanvaarbaar, neerstort, onbereikbaar which are to be found in the articles of onder-, on- and neer-. In lexicographic theory this type of lemma sign is known as a sublexical lemma sign or hyphenated lemma sign. It is inter alia a space saving method of lemmatisation.

Sublexical lemma signs in the WAT receive microstructural treatment in the form of a phonetic transcription, a lemma sign classification like 'prefix used to form adjectival derivatives' in the case of on- 'un-', a definition and synonyms or antonyms. The definition is followed by examples of compounds or derivatives formed with the prefix, suffix or stem lemmatised as a sublexical lemma sign. Examples in italics are also lemmatised with full microstructural treatment 'as articles in their own right'. Examples in bold print are not lemmatised 'as articles in their own right', but are rather sublemmatised under the sublexical lemma and stress is indicated in each case (see figure 2). It is thus not really a case of the dictionary becoming 'a list of words', as the listed examples and sublemmas are preceded by a phonetic transcription, a lexical item classification, a definition and synonyms or antonyms of the affix or stem lemmatised as sublexical lemma sign.

A relevant question therefore is: Which is more meaningful: the listing and sublemmatisation of examples of derivatives or compounds in the article of a sublexical lemma sign like on- with an overarching definition like nie 'not', or many more pages with lemma signs with individual definitions stating that the derivative with on- implies the negative or opposite of the meaning of the stem of the lemma sign? The WAT chose the former lemmatisation 


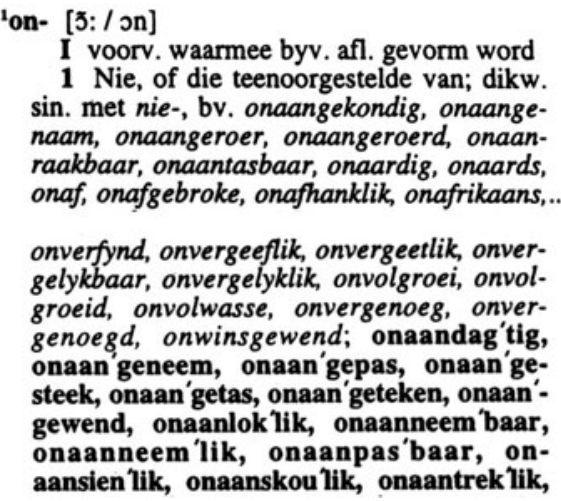

Figure 2:

and sublemmatisation method. Sublexical or hyphenated lemma signs are an accepted method of lemmatisation. The examples listed in bold are regarded as sublemma signs and are as such part of the macrostructure of the dictionary.

On the issue of references from previous volumes that are not honoured in volume XI, I can state that in some instances De Schryver is right that references were overlooked. The advanced search functions provided by the electronic WAT could aid in the elimination of such errors in future. In other instances there are good reasons for not honouring references. From volume IX of the WAT editors are no longer bound to honour references from preceding volumes, which do not reflect the present language reality of Afrikaans and this is fully accounted for in the Introduction of volume IX (p. ii under 1.7). Therefore nie-opportuun, orologie, nommerskyf, onbesweke and netweefsel were for instance not included in volume XI resulting in a 'dead cross-reference'.

Category four: 'lemma signs that have not been lemmatised, and do not occur anywhere in the WAT text either', namely onwis (in the expression 'vir die wis en die onwis' 'for all circumstances'), onknap 'not without brains', naggesig 'vision', onfris 'unwell', nyg 'bow', onbeskryfbaar 'indescribable', omblaas 'blow down'.

Limited space does not allow me to discuss all examples given by De Schryver but he is right regarding onknap, onfris, omblaas which could have been included in the articles of the sublexical lemmas on- and om- as the typical and the frequently used examples are included to illustrate the range of derivatives formed. It is, however, an unfortunate reality that even comprehensive dictionaries have to include only a representative grouping of compounds and derivatives to exemplify typical morphological processes. nyg was a borderline case for inclusion. Preference was given to the much 
more frequently used Afrikaans spelling neig over the adapted spelling from the Dutch nijg. It was included as ${ }^{2}$ neig. Besides its inclusion in Afrikaans desk dictionaries nyg is almost only found in linguistic publications where its meaning and spelling are discussed. Only one record in our data resources can be described as an example of natural language. This record is from a poet with an inclination for Dutchisms.

Category five: ' $n$ - and o-initial HAT items that have not been entered in WAT - either as lemmas, as sub-lemmas or as run-ons - despite the fact that those very same items are used throughout the WAT text itself', namely nekwerwel 'neck vertebra', onversigtigheid 'carelessness', onuitputlik 'inexhaustible, nommerskyf 'dial', netweefsel 'filet', naburig 'neighbouring', onkenbaar 'unthinkable' and onverboë 'uninflected'. I am limited to the discussion of a few examples only.

nekwerwel, onversigtigheid, onuitputlik, onkenbaar and onverboë could have been lemmatised or sublemmatised in WAT as they are well represented in our data resources and are also used in the WAT text itself. In the compilation process editors now have access to the electronic WAT, which will help to achieve more consistency in our lemmatisation and sublemmatisation. naburig was lemmatised in WAT in its inflected form naburige since this is the form in which it is most frequently used. In the Nasionale Pers Archives alone, naburige features 3,391 times and naburig only once. In the WAT text naburig features twice and naburige 89 times. For similar reasons opvoerreg was lemmatised in the plural form opvoerregte.

Mention is also made of unhonoured cross-references like onbesweke and orologie. onbesweke does not feature in our electronic data resources and there is one record in the card collection. The single record is from a theological publication of 1965. Afrikaans theological publications of that time are characterised by a strong Dutch influence and formal, tending to grandiose or ephemeral language. It is also found in Afrikaans desk dictionaries, but in our view it is an example of the tendency of these dictionaries to include Dutchisms. Onbesweke was therefore not seen as part of the established Afrikaans vocabulary and the reference was not honoured. orologie does not feature in our electronic data resources and there are only two records in the card collection. Our collaborators for geography confirmed that orologie is not a recognised geographic term in Afrikaans. The reference to orologie in volume I of the WAT was therefore not honoured.

\section{On the way ahead}

Three suggestions are made by De Schryver to steer future compilation of the WAT. The WAT strives to reconcile lexicographic theory and practice and will therefore give serious consideration to the suggestions. 
The first suggestion is that a large electronic corpus should be built and effectively used to complement the current manually compiled citation collection. This 'will avoid a situation whereby further frequent items are not given lemma-sign status'. Using the current WAT text itself as its own corpus and regular comparisons with existing Afrikaans dictionaries should also be considered. Since the completion of volume XI ( $\mathbf{N}$ and $\mathbf{O}$ ) the editors have had access to three electronic data resources including the Afrikaans Newspaper Corpus. They are also in a position to use the Electronic WAT to ensure that valid lexical items in the metatext are included and that valid references are honoured. Unfortunately the electronic WAT only became available midway through the compilation of volume XII. It has, however, been used extensively since and a word list with frequency counts has been generated to help guide editors in deciding on inclusion. We trust that the combination of citation collections and corpora we now employ, provides a relatively accurate picture of general language in its written and spoken form. Steps are also taken to gain access to further resources, specifically a corpus of spoken Afrikaans.

We are therefore of the opinion that editors are presently in a better position than ever to come to well informed conclusions about the Afrikaans vocabulary. We are, however, more than willing to exchange views with the author on the degree of representativeness of the sources and on how it may be improved. Regular comparisons have always been made with existing Afrikaans desk dictionaries. The inclusion of an item in another dictionary or word list is, however, not considered as proof of its existence by the WAT. Proof has to be found of the item's use in real or natural language and if the data resources of the WAT does not provide such proof from three different sources by three different authors as minimum requirement, the item cannot be included.

Secondly it is suggested that a Ruler for Afrikaans can be drawn on to help manage the project. We would like to co-operate in the refining of a Ruler for Afrikaans as we do not want to repeat the mistakes of the past. We realise, however, that just like we have reservations about whether the data resources on which the Ruler is based, can be considered as balanced and can give frequency counts that accurately reflect Afrikaans, similar doubts may exist about our resources.

Lastly it is suggested that concurrent over- and under-treatment ought to be monitored. We have already benefited from the information in the article about concurrent over- and under-treatment in the WAT and we would like to continue the discussion on the monitoring thereof with the author.

\section{References}

Béjoint, H. 1999. 'Compound Nouns in Learners' Dictionaries'. In T. Herbst and K. Popp (eds.), The Perfect Learners' Dictionary (?). Tübingen: Max Niemeyer Verlag, 113-130. 
Botha, W. 1994. 'An About-Turn Halfway Through the Completion of a Multi Volume Overall-Descriptive Dictionary - Gallantry or Folly?'. In W. Martin, W. Meijs, M. Moerland, E. ten Pas, P. G. J. van Sterkenburg and P. Vossen (eds.), Euralex 1994 Proceedings, Papers submitted to the 6th EURALEX International Congress on Lexicography in Amsterdam, The Netherlands. Amsterdam: Vrije Universiteit, 419-25.

Botha, W. 2003. Die impak van die leksikografieteorie op die samestelling van die Woordeboek van die Afrikaanse Taal. Unpublished doctoral thesis. Stellenbosch: University of Stellenbosch.

Gouws, R. H. 1999. 'Mediostructural representation, textual condensation and user-orientation in the WAT X'. Lexicographica: International Annual for Lexicography 15: 4-37.

Odendal, F. F. 2003. 'Bevry ons tog leksikografies van Nederlands'. In W. Botha (ed.), 'n Man wat beur. Huldigingsbundel vir Dirk van Schalkwyk. Stellenbosch: Bureau of the WAT, 286-293.

Prinsloo, A. F. 1991. 'Woordeboek en gebruik: 'n bose kringloop'. Lexikos 1: 197-220.

Prinsloo, D. J. and G.-M. De Schryver. 2002. 'Designing a Measurement Instrument for the Relative Length of Alphabetical Stretches in Dictionaries, with special reference to Afrikaans and English'. In A. Braasch and C. Povlsen (eds.), Proceedings of the Tenth EURALEX International Congress, EURALEX 2002, Copenhagen, Denmark, August 13-17, 2002. Copenhagen: Center for Sprogteknologi, Københavns Universitet, 483-494.

Prinsloo, D. J. and G.-M. De Schryver. 2003. 'Effektiewe vordering met die Woordeboek van die Afrikaanse Taal soos gemeet in terme van 'n multidimensionele Liniaal'. In W. Botha (ed.), 'n Man wat beur. Huldigingsbundel vir Dirk van Schalkwyk. Stellenbosch: Bureau of the WAT, 106-126.

Wiegand, H. E. 1989. 'Aspekte der Makrostruktur im allgemeinen einsprachigen Wörterbuch: Alphabetische Anordnungsformen und ihre Probleme'. In F. J. Hausmann et al. (eds.), Wörterbücher. Dictionaries. Dictionnaires. An International Encyclopedia of Lexicography, Berlin: De Gruyter, 371-409.

Wiegand, H. E. 2002. 'Über textuele Strukturen der Wörterbuchartikel und Artikelnischen im de Gruyter Wörterbuch Deutsch als Fremdsprache'. In H. E. Wiegand (ed.). Perspektiven der pädagogischen Lexikographie des Deutschen II, Tübingen: Max Niemeyer, 497-595.

Wiegand, H. E. 2002a. 'Zur Makrostruktur und zu den äußeren Zugriffsstrukturen im de Gruyter Wörterbuch Deutsch als Fremdsprache'. In H. E. Wiegand (ed.), Perspektiven der pädagogischen Lexikographie des Deutschen II, Tübingen: Max Niemeyer, 413-442.

Wolski, W. 1989. 'Das Lemma und die verschiedenen Lemmatypen'. In F. J. Hausmann et al. (eds.), Wörterbücher. Dictionaries. Dictionnaires. An International Encyclopedia of Lexicography, Berlin: De Gruyter, 360-371. 